九州歯会誌 $36(6) ： 932 ９ 39 ， 1982$.

\title{
根管治療剤ホルマリン・グアヤコールの急性毒性
}

九州歯科大学歯科薬物学講座（指導：吉村泰治教授)

黒木 賀代子・村 上 雄 次
大 住 伴 本 村

昭和 57 年10月 5 日受付

\section{A Study on Acute Toxicity of Formalin-Guaiacol}

Kayoko Kuroki, Yuji Murakami, Tomoko Osumi and Tamaki Kimura

Department of Dental Pharmacology (Professor : Prof. Taiji Yoshimura)

Kyushu Dental College, Kitakyushu, Japan

Acute toxicity of Formalin-guaiacol(FG) was studied in comparison with that of Formocresol(FC), guaiacol and cresol with use of male mice of ddY strain weighing about $20 \mathrm{~g}$ each. Each drug was diluted in olive oil to be administered orally to the mice which had not been fed for 20 hours prior to the test. Toxic symptoms and changes in the body weight gain were observed and the number of death was recorded for 7 days; $\mathrm{LD}_{50}$ with $95 \%$ confidence limits calculated by Litchfield-Wilcoxon's method was : $1.81(1.56 \sim 2.10) \mathrm{g} / \mathrm{kg}$ for $\mathrm{FG}, 1.72(1.51 \sim 1.96) \mathrm{g} / \mathrm{kg}$ for $\mathrm{FC}, 0.89(0.75 \sim$ $1.05) \mathrm{g} / \mathrm{kg}$ for guaiacol and $0.76(0.66 \sim 0.87) \mathrm{g} / \mathrm{kg}$ for cresol. No significant difference was found between $\mathrm{LD}_{50}$ of $\mathrm{FG}$ and that of $\mathrm{FC}$ or between $\mathrm{LD}_{50}$ of guaiacol and that of $\operatorname{cresol}(\mathrm{p}<0.05)$. Little difference was observed between guaiacol and cresol, and FG bore much resemblance to $F C$ concerning toxic symptoms and changes in the body weight gain of surviving mice induced by oral administration of each drug.

From the above it was considered that FG was less toxic than guaiacol and than cresol and that toxicity of FG was as potent as that of FC.

緒言

ホルマリン・クレゾール製剤は感染根管消毒剤として 古くから繁用されているが，根管治療上，所要条件を完 備した薬剤とは言えない，他剤に比較して卓越した消毒 才を示す ${ }^{(-6)}$ 反面, その局所刺激作用や寉蝕作用も強く 7ー9)，また，製剤変化を起乙し易(10-12)点には十分に 注意しなければならない。このような欠点を改良する目 的で, クレゾール以外のフェノール系薬羭, あるいは界 面活性剈などをホルマリンに配合した製剤が試作された 13,14). 中でも，ホルマリン・グアヤコール製戍は，感
染根管に対してホルマリン・クレゾール製剤に劣らぬ臨 床成績が得られるといわれ14ー17)，その薬理作用や毒 性, 経時変化についても検討されるに至った18-20).

ホルマリン・グアャコール製剤の急性毒性について は, 既に西川ら $(1978)^{18) ， お よ ひ ゙ 二 木 ら ~}(1979)^{193}$ ， $(1979)^{201}$ により報告されている．しかし，ホルマリン ・グアャコール製剤とホルマリン・クレゾール製戍ある いは単味のグアヤコールとの比較成績では必ずしも一致 した傾向が認められなかった。本実験ではこの点を明ら かにするため，マウスにおける $50 \%$ 致死量（以下 $\mathrm{LD}_{50}$ と記す）を求めることにより，ホルマリン・グアヤコー 
ル (以下 FG と記す), ホルモクレゾール（以下 FC と 記す)，グアャコールおよびクレゾールの急性毒性を比 較検討した。

\section{実 験 方 法}

\section{A 、実験動物ならびに飼育条件}

実験動物は体重18.0 22.0 g の ddY 系雄性マウス350 匹を用いた，飼料は固型飼料（オリエンタルMF）を用 い，飲料水と共に自由に摄取できるようにしたが，薬物 投与前 20 時間は絶食とした。ママウスは購入後実験環境に 一週間観察飼育を行い，外貌，行動および体重変化に異 常の認められなかったものだけを使用した。

\section{B . 実験薬剤}

実験薬戍は次の 4 種とした。

1. $F G$

$$
\begin{array}{ll}
\text { ホルマリン } & 40.0 \% \\
\text { グアャコール } & 40.0 \% \\
\text { エチルアルコール } & 20.0 \%
\end{array}
$$

2. $\mathrm{FC}$

$$
\begin{array}{ll}
\text { ホルマリン } & 40.0 \% \\
\text { クレゾール } & 40.0 \% \\
\text { エチルアルコール } & 20.0 \%
\end{array}
$$

3. グアヤコール

4. クレゾール

上記薬浏のうち，ホルマリンとエチルアルコールは試 薬特級品, クレゾールは試薬一級品の 3 異性体をそれぞ れ用時精製し， $o$ 体 $35.0 \% ， m$ 体 $40.0 \% ， p$ 体 $25.0 \%$ の 割合に混和したもの，グアャコールは片山化学工業製最 純試薬を使用し，FG および FC は新しく調製したもの を用いた。

\section{C. 実験群ならびに投与方法}

実験群はいずれも 1 群10四とした。

薬剂投与は，13時30分から14時30分の間に行い，投与 直前にマウスの体重を測定した.

実験薬剤は，日本薬局方オリーブ油で所定の濃度（g/ dl）に稀釉し，マウス体重 $10 \mathrm{~g}$ あたり薬剤溶液 $0.1 \mathrm{ml}$ を 胃ゾンデを用いて経口投与した。コントロール群には， オリーブ油をマウス体重10 g あたり0.1ml投与した .

D . 死亡数ならびにLD ${ }_{50}$

薬斉投与後 7 日間にわたり死亡数を記録し，総死亡数 から Litchfield-Wilcoxon 法" ${ }^{\prime \prime} に よ り L_{50}$ を求めた。

E. 全身症状ならびに体重変化

薬剤投与後 7 日間にわたり全身症状の観察と生存例の 体重測定を行った．体重は 1 例ごとに楽剤投与前の体重
に対する比率を求め，各実験群の平均值をグラフに表し て体重変化を調べた。

\section{実 鋻 成}

A · 死亡数ならびに $\mathrm{LD}_{50}$

$\mathrm{FG}, \mathrm{FC}$,グアヤコールおよびクレゾールを投与後 7 日 間の死亡数は表 1 および図 $1 ， 2$ に示す通りであった.こ れから $\mathrm{LD}_{50}$ とその95\%信頼限界を求めると，FGは1.81 $\mathrm{g} / \mathrm{kg}(1.56 \sim 2.10 \mathrm{~g} / \mathrm{kg}), \mathrm{FC}$ は $1.72 \mathrm{~g} / \mathrm{kg}(1.51 \sim 1.96$ $\mathrm{g} / \mathrm{kg})$ であり，また，グアヤコールは0.89g/kg（0.75 $\sim 1.05 \mathrm{~g} / \mathrm{kg})$, クレゾールは0.76g/kg $(0.66 \sim 0.87 \mathrm{~g} / \mathrm{kg})$ となったＦG を比較基準とすると FC，グアヤコール 抢よびクレゾールの用量一反応直線はいずれも平行性 を有し，毒性比を求めると表 2 亿示すように FG 1.00 に対し，FC 1.05，グアャコール2.03, クレゾール2.38 となった，しかし，FGと FCの間およびグアャコール とクレゾールの間に有意差は認められなかった（危険率 $5 \%$ ).

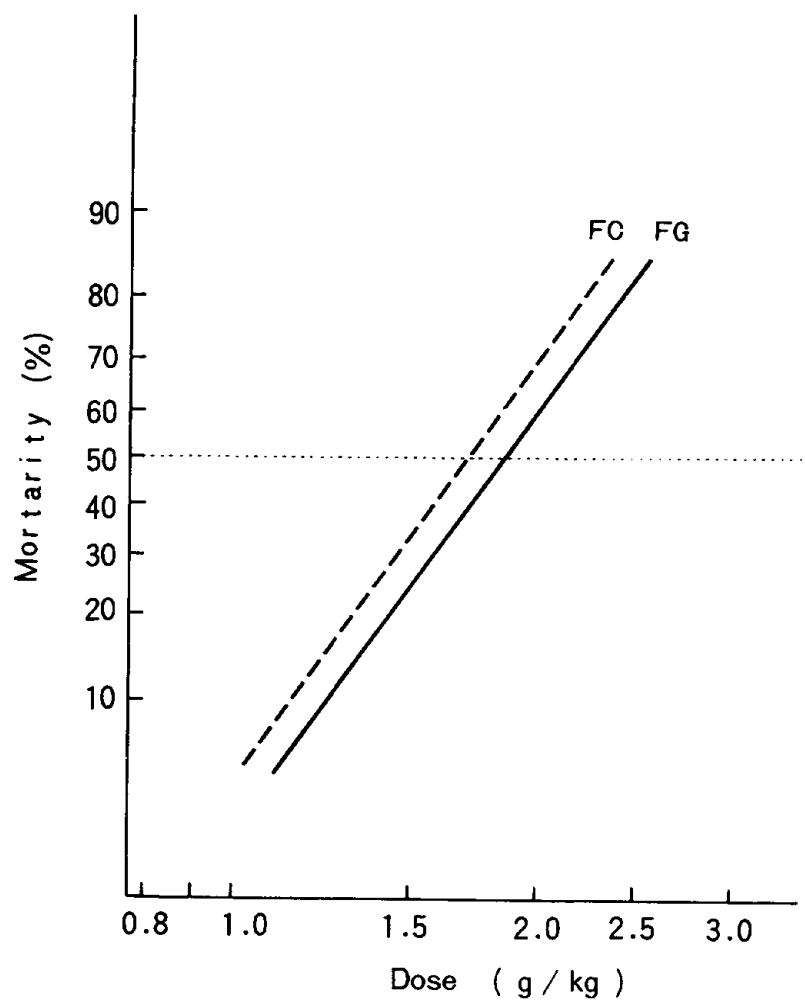

Fig. 1 Dose-response lines of $F G$ and $F C$ on mortality in mice. 
Table 1 Mortality of mice caused by oral administration of FG, FC, guaiacol and cresol.

FG

\begin{tabular}{|c|c|c|c|c|c|c|c|c|c|}
\hline \multirow{2}{*}{$\begin{array}{c}\text { Dose } \\
(\mathrm{g} / \mathrm{kg})\end{array}$} & \multirow{2}{*}{$\begin{array}{l}\text { Number of } \\
\text { experimental } \\
\text { mice }\end{array}$} & \multicolumn{7}{|c|}{ Days after administration } & \multirow{2}{*}{$\begin{array}{c}\text { Total number } \\
\text { of death }\end{array}$} \\
\hline & & 1 & 2 & 3 & 4 & 5 & 6 & 7 & \\
\hline $1 \cdot 10$ & 10 & 1 & 0 & 0 & 0 & 0 & 0 & 0 & 1 \\
\hline $1 \cdot 30$ & 10 & 1 & 0 & 0 & 0 & 0 & 0 & 0 & 1 \\
\hline 1.60 & 10 & 3 & 0 & 0 & 0 & 0 & 0 & 0 & 3 \\
\hline 1.90 & 10 & 6 & 0 & 0 & 0 & 0 & 0 & 0 & 6 \\
\hline 2.30 & 10 & 10 & 0 & 0 & 0 & 0 & 0 & 0 & 10 \\
\hline
\end{tabular}

FC

\begin{tabular}{|c|c|c|c|c|c|c|c|c|c|}
\hline \multirow{2}{*}{$\begin{array}{l}\text { Dose } \\
(\mathrm{g} / \mathrm{kg})\end{array}$} & \multirow{2}{*}{$\begin{array}{l}\text { Number of } \\
\text { experimental } \\
\text { mice }\end{array}$} & \multicolumn{7}{|c|}{ Days after administration } & \multirow{2}{*}{$\begin{array}{c}\text { Total number } \\
\text { of death }\end{array}$} \\
\hline & & 1 & 2 & 3 & 4 & 5 & 6 & 7 & \\
\hline 1.10 & 10 & 0 & 0 & 0 & 0 & 0 & 0 & 0 & 0 \\
\hline 1.30 & 10 & 1 & 0 & 0 & 1 & 0 & 0 & 0 & 2 \\
\hline 1.60 & 10 & 4 & 0 & 0 & 0 & 0 & 0 & 0 & 4 \\
\hline 1.90 & 10 & 5 & 0 & 0 & 0 & 0 & 0 & 0 & 5 \\
\hline 2.30 & 10 & 9 & 0 & 0 & 0 & 0 & 0 & 0 & 9 \\
\hline
\end{tabular}

Guaiacol

\begin{tabular}{c|l|l|l|l|l|l|l|l|l}
\hline \hline \multirow{2}{*}{$\begin{array}{c}\text { Dose } \\
(\mathrm{g} / \mathrm{kg})\end{array}$} & $\begin{array}{l}\text { Number of } \\
\text { experimental } \\
\text { mice }\end{array}$ & \multicolumn{6}{|c|}{ Days after administration } & Total number \\
\cline { 3 - 9 } & 1 & 2 & 3 & 4 & 5 & 6 & 7 & of death \\
\hline 0.56 & 10 & 0 & 0 & 0 & 0 & 0 & 0 & 0 & 0 \\
0.67 & 10 & 1 & 1 & 0 & 0 & 0 & 0 & 0 & 2 \\
0.80 & 10 & 3 & 0 & 0 & 0 & 0 & 0 & 0 & 3 \\
0.97 & 10 & 5 & 0 & 0 & 0 & 0 & 0 & 0 & 5 \\
1.20 & 10 & 9 & 0 & 0 & 0 & 0 & 0 & 0 & 9 \\
1.40 & 10 & 9 & 0 & 0 & 0 & 0 & 0 & 0 & 9 \\
\hline
\end{tabular}

Cresol

\begin{tabular}{c|l|r|r|r|r|r|r|r|r|r}
\hline Dose & $\begin{array}{l}\text { Number of } \\
\text { experimental } \\
\text { mice }\end{array}$ & \multicolumn{6}{|c|}{ Days after administration } & Total number \\
\cline { 3 - 9 } & 1 & 2 & 3 & 4 & 5 & 6 & 7 & of death \\
\hline 0.56 & 10 & 0 & 0 & 0 & 0 & 0 & 0 & 0 & 0 \\
0.67 & 10 & 4 & 0 & 0 & 0 & 0 & 0 & 0 & 4 \\
0.80 & 10 & 6 & 0 & 1 & 0 & 0 & 0 & 0 & 7 \\
0.97 & 10 & 7 & 1 & 0 & 0 & 0 & 0 & 0 & 8 \\
1.20 & 10 & 9 & 0 & 0 & 0 & 0 & 0 & 0 & 9 \\
1.40 & 10 & 10 & 0 & 0 & 0 & 0 & 0 & 0 & 10 \\
\hline
\end{tabular}


Table 2 Comparison of acute toxicities of FG, FC, guaiacol and cresol in mice.

\begin{tabular}{l|cc|c}
\hline \multicolumn{1}{c|}{ Sample } & LD $_{50}$ & $(\mathrm{~g} / \mathrm{kg}, \mathrm{p.0.})$ & Toxic potency ratio \\
\hline FG & 1.81 & $(1.56 \sim 2.10)$ & 1.00 \\
\hline FC & 1.72 & $(1.51 \sim 1.96)$ & $1.05 \quad(0.87 \sim 1.27)$ \\
\hline guaiacol & 0.89 & $(0.75 \sim 1.05)$ & $2.03 \quad(1.62 \sim 2.54)$ \\
\hline cresol & 0.76 & $(0.66 \sim 0.87)$ & $2.38 \quad(1.95 \sim 2.90)$ \\
\hline
\end{tabular}

( ) ;95\% confidence limits

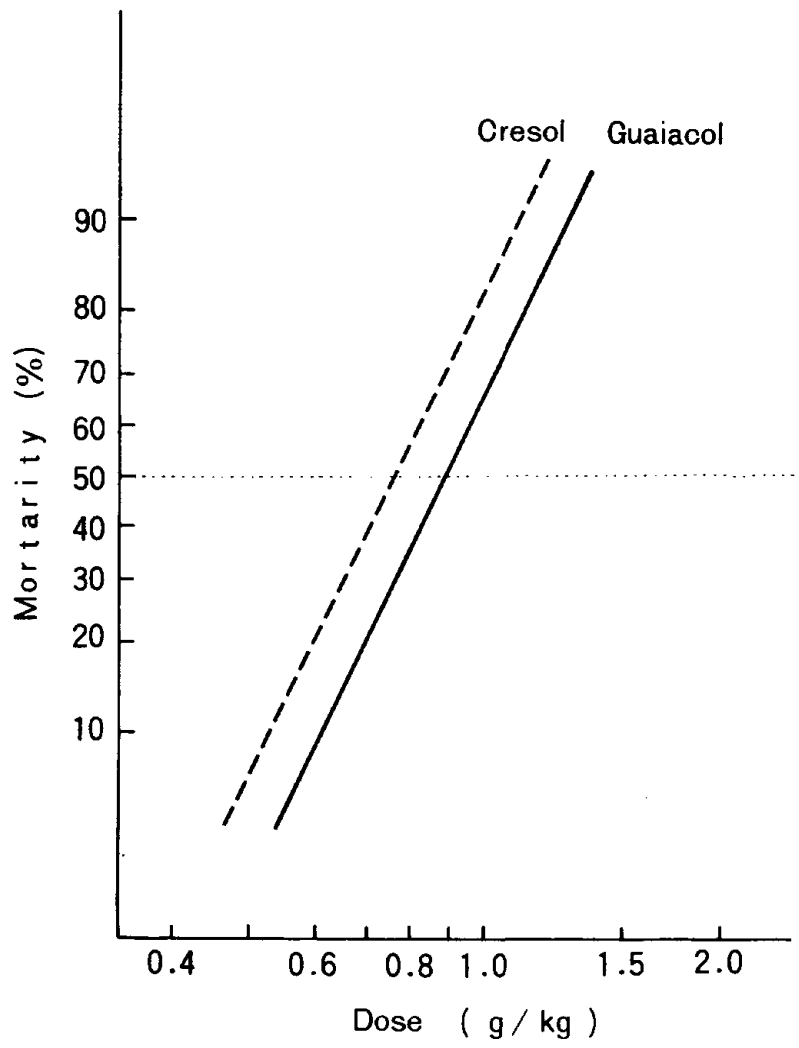

Fig. 2 Dose-response lines of guaiacol and cresol on mortality in mice.

\section{B ．全身症状ならびに体重変化}

\section{1. $\mathrm{FG}$}

FG の経口投与時に観察された全身症状は，用量 1.10 $\mathrm{g} / \mathrm{kg}$ では投与後 $10 \sim 15$ 分で10例全てに自発運動六進が みられ，4例に洗顔運動もみられた．その後 2 例はしだ いに回復に向かったが，他の 8 例では自発運動がしだい に減じ，40〜50分後には眼裂縮小，立毛が明らか記認め られるようになった．この8 例中 3 例はその後しだいに 回復したが，5例はやがて著しい歩行失調ならびに振戦
を起こし，その数分後には痤彎を起こして全身側位とな った. 約20〜30分で 4 例は回復に向かい，投与後 $3 \sim 4$ 時間後には正常な姿勢をとり, 自発運動が可能となっ た. 他の 1 例のみは痤絲状態から回復し得ず，しだいに 麻㾇へと移行し， 3 時間後に死亡した．用量を增すに従 って，上記の症状はより速やかに，激しく現われるよう になり，歩行失調を起しした時点では皮膚，粘膜がやや 荅白となり，チアノ一ゼも恝められれた．用量 $2.30 \mathrm{~g} / \mathrm{kg}$ では投与後 $2 \sim 5$ 分で歩行失調, 立毛が顕著となり, 10 〜20分後に激しい痙等を起しし，大多数の例では全身側 位となり，一部のものは伏臥位のままでしだいに麻㿉状 態へ移行し， 1 時間以内に全例が呼吸停止により死亡し た。

FG の各用量における生存例の体重変化は図 3 亿示す 通りで，今回実験した $1.10 \mathrm{~g} / \mathrm{kg}$ 以上の用量では，い ずれの群も投与後 2 日目まで著しい体重の減少がみられ た. その後, 徐々に増加し，3〜5日でほぼ投与前の体

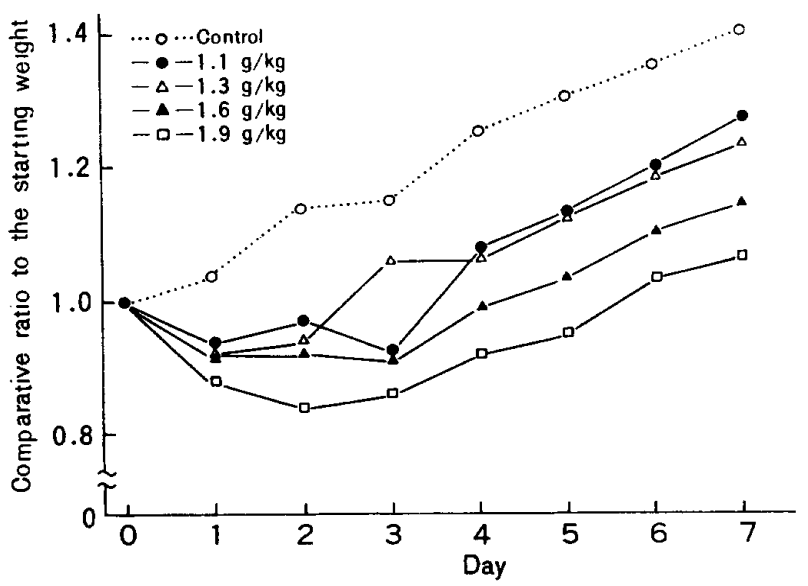

Fig. 3 Change in the body weight gain of surviving mice induced by oral administration of $\mathrm{FG}$. 
重に回復したが，コントロール群に比較すると，明らか に低い值となり，7日後における体重をコントロール群 に比較すると， $1.10 \mathrm{~g} / \mathrm{kg}$ 投与群は $91 \%, 1.30 \mathrm{~g} / \mathrm{kg}$ 投与 群は $88 \% ， 1.60 \mathrm{~g} / \mathrm{kg}$ 投与群は $81 \% ， 1.90 \mathrm{~g} / \mathrm{kg}$ 投与群は $76 \%$ であった. 立毛は $1.30 \mathrm{~g} / \mathrm{kg}$ 以下では $3 〜 4$ 日後に 回復したが，それ以上の用量では 5 日以上を要した。

\section{2. $\mathrm{FC}$}

$\mathrm{FG}$ と同用量のFCを経口投与した場合にみられる全身 症状は，FG の場合とほとんぞ同椂であった。また，各

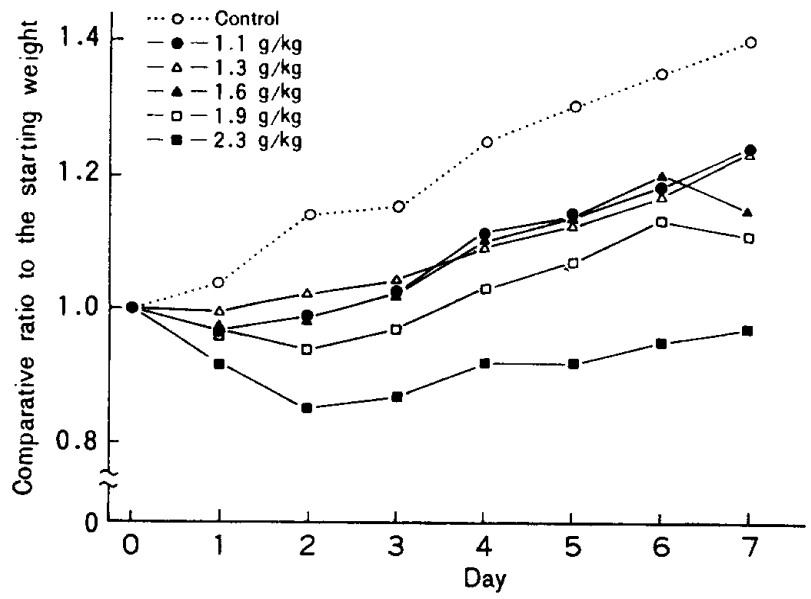

Fig. 4 Change in the body weight gain of surviving mice induced by oral administration of $\mathrm{FC}$.

用量における生存例の体重変化も FG の場合とほぼ同様 の傾向を示した（図4).

3. グアヤコール

グアヤコールの経口投与による全身症状は，用量0.56 $\mathrm{g} / \mathrm{kg}$ では投与後 3 〜 15分で全例に自発運動の㧕制ある いは停止, 続いて振戦, 立毛がみられ，10〜20分後に 7 例は下半身麻瘦，他の 3 例は激しい痤攀を起こして全身 側位となった。この時期には眼裂縮小が著しく，頻繁に 注鳴を発した。このように激しい中毒症状を呈したが， $0.56 \mathrm{~g} / \mathrm{kg}$ 投与群では，40〜60分後より全例が回復に向 かい， 3 時間後には自発運動が可能となった。しかし， 用量を增加するに従って，投与後間もなく振戦と流涎が みられるようになり，やがて激しい痤攀を起てし，全身 側位となったまま麻痺状態から呼吸停止に至る例数が増 加した.

グアヤコールの各用量における生存例の体重変化は図 5 に示す通りで，いずれの用量でも投与後体重は減少 し， その影響は $2 \sim 3$ 日後まで強く認められた。，その 後, 体重は增加し, $0.56,0.67,0.80 \mathrm{~g} / \mathrm{kg}$ 投与群では
4 日後, $0.97 \mathrm{~g} / \mathrm{kg}$ 投与群では 5 日後, $1.20,1.40 \mathrm{~g} / \mathrm{kg}$ 投与群では 6 日後にほぼ投与時の体重まで回復した。コ ントロール群に比較すると，いずれの群も著しく低い值 となっており，7日後ておいても，投与群の体重はコン トロール群の75〜85\%であった（困 5 ). 立毛は0.80g/ $\mathrm{kg}$

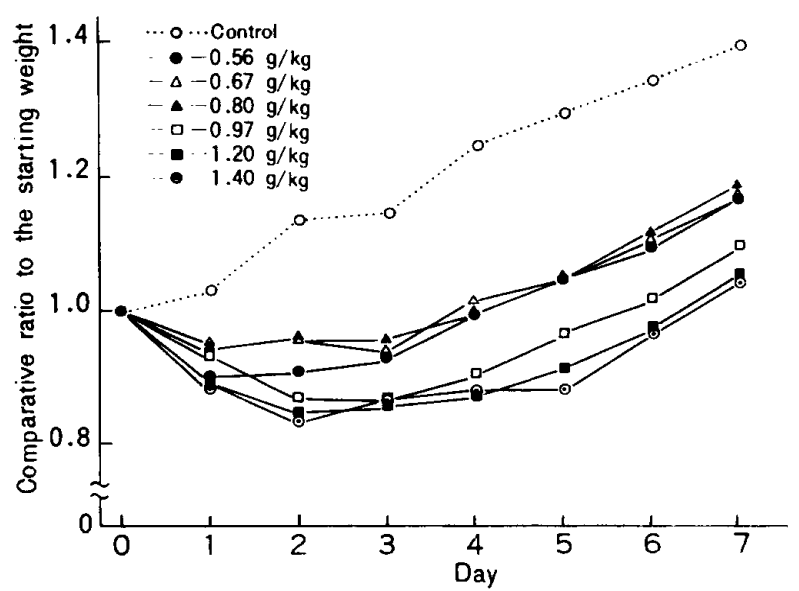

Fig. 5 Change in the body weight gain of surviving mice induced by oral administration of guaiacol.

以下では 4〜 5 日後に認められなくなったが, $0.97 \mathrm{~g} / \mathrm{kg}$ 以上では回復に 5 日以上を要し， $1.40 \mathrm{~g} / \mathrm{kg}$ では 7 日後 においても回復しなかった。

4. クレゾール

グアヤコールと同一用量のクレゾールを経口投与した 場合にみられた全身症状は，グアヤコールの場合とほと んど同様であったまた，各用量における生存例の体 重変化にもグアヤコールと同様の傾向が喼められた（図 6 ).

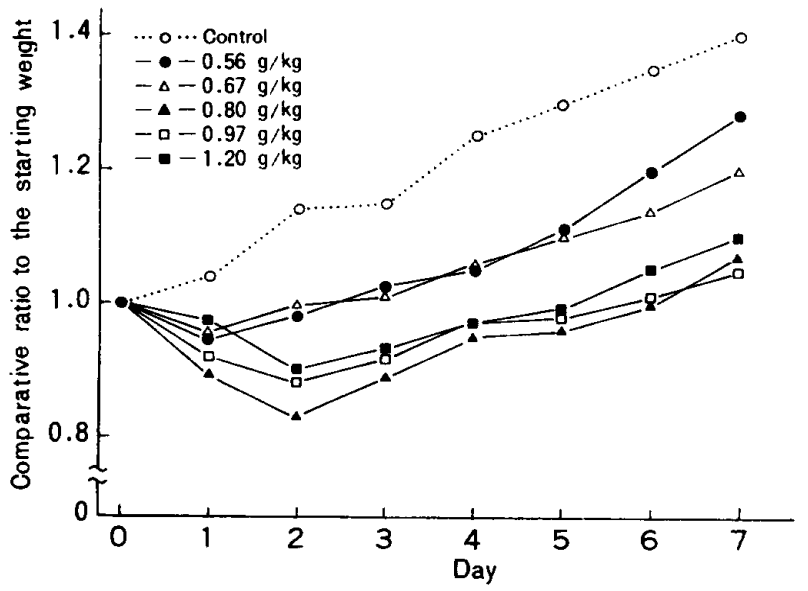

Fig. 6 Change in the body weight gain of surviving mice induced by oral administration of cresol. 
考

察

FGの急性毒性とFCのそれとの比較については，すで に西川ら (1978) 18)，および二木ら(1979)19'により検討 され，いずれも雄性マウスに経口投与した場合の $\mathrm{LD}_{5} 0$ が報告された．前者によれば FG の $\mathrm{LD}_{50}$ は $1.64 \mathrm{~g} / \mathrm{kg}$

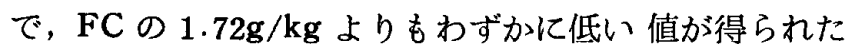
が，両薬剤のLD o $_{0}$ 亿は有意差が認められず，また，観 察された一般症状からもFGとFCの急性毒性には差異が 認められなかった。しかし，後者によれば，FG および $\mathrm{FC} L D_{5}$ ははそれぞれ0.996g/kg，0.909g/ $\mathrm{kg}$ で，逆に FCの方が低い值となり，FCの毒性はFGのそれよりも 強いと思われた。本実験で得られたFGと FCの $\mathrm{LD}_{5}$ は それぞれぞれ $1.81 \mathrm{~g} / \mathrm{kg} ， 1.72 \mathrm{~g} / \mathrm{kg}$ で FGはFCよりもわ ずかに高い值となったが，両薬剤の $\mathrm{LD}_{5}$ には有意差は 彗められず，生存例の体重変化もほぼ同様の傾向を示し た・したがって，西川らの述べるようにFGと FC の急 性毒性にはほとんど差異はないものと考えられる。ま た，FGと FCの経口投与時に現われる中毒症状も互いに 類似しており，差異は認められなかった。

次に，FGに40\%配合されているグアャコールと，FC に40\%配合されているクレゾールを, 各々単味でマウス

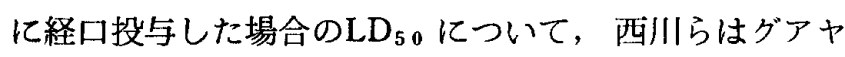
コールは $1.09 \mathrm{~g} / \mathrm{kg}$ ，クレゾールは $0.99 \mathrm{~g} / \mathrm{kg}$ であり，グ

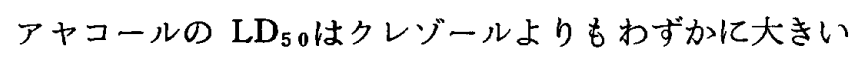
程度で大差はないと考えた。しかし，二木らは，グアヤ コールおよびクレゾールの $\mathrm{LD}_{5} 0$ はそれぞれ $1.231 \mathrm{~g} / \mathrm{kg}$ および1.117g/kgで， クレゾールの毒性はグアャコール のそれよりも強く，乙の毒性の差がそのまま合剤の FG と FCの毒性の差として出現したものと思われる，と述 ベている. 本実験の結果, グアヤコールおよびクレゾー

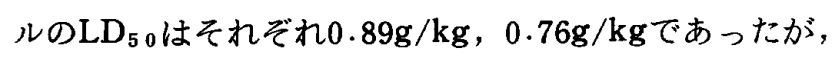
検定の結果両薬剂間に有意差は認められず，また，全身 症状および生存例の体重変化にも差異は認められなか った・したがって，グアャコールとクレゾールの急性毒 性にはほとんど差異はないものと考えられる。黒木ら $(1980)^{22}$ は既にクレゾールがフェノールと類似の中毒 症状を呈することを観察したが，同じフェノール系薬羭 のグアヤコールもまた，それと非常によく似た症状を呈 することが本実験で確慧された。

前述のように本奏験で得た FGおよびFCの $\mathrm{LD}_{5} 0$ は西 川らの報告した值に近いが，二木らの值よりもかなり高 かった・また，グアャコールおよびクレゾールのLD50 は西川ら，二木らいずれの值よりも低かった・しかし，
グアヤコールおよびクレゾールに比べてそれぞれの合剤 であるFGおよびFCは毒性がかなり低いという点では西 川らの報告と一致した。薬物の急性毒性実験には，試験 環境, 気侯風土, 実験動物の差異などの他に集団特性, バイオリズムなども関与し，また薬物の投与方法ととも に浴媒や濃度によっても実験成績は左右される21，23． このように多数の因子が関与するので，ほとんど同一条 件下で行ったと報告された実験であっても実験場所が異 れば, 季節, 天候, 日時など, 個々の因子の微妙な差異も 集積して $\mathrm{LD}_{50}$ 值に影響を与えるようになるであろう. そのために上記のような $\mathrm{LD}_{50}$ 值の差異を生じたものと 思われる . 黑木ら $(1980)^{22}$ が今回と同一条件下で行っ たクレゾールとホルマリンの急性毒性実験では, クレゾ ールの LD $\mathrm{LD}_{5}$ は $0.81 \mathrm{~g} / \mathrm{kg}$ であったが，それと今回得た $0.76 \mathrm{~g} / \mathrm{kg}$ との間に有意差は認められず，両者はほぼ一 致した（危険率 $5 \%$ ). 数種類の薬剤について毒性を比 較する場合には, 各薬剤についての試験を同時に平行し て実施することが望ましい。しかし，実際上，それを可 能とする薬剤の数には限りがある. 止むを得ず数回に分 けて行う時は，一定の薬剤をポジティブ・コントロール とし，乙れに対する毒性比を求めておくと非常に参考に なる.黒木ら $(1980)^{221}$ の実験成績でホルマリンのクレ ゾールに対する毒性比を求めると約 1.2 となり, ホルマ リンの方が毒性は強かった。乙の結果と今回の実験成績 とから，グアャコールとホルマリンの毒性を比較する ならばホルマリンの方が毒性は高いであろうと考えられ る. 実際に二木ら $(1979)^{19}$ は実験によりホルマリンの 毒性がグアャコールよりも強いことを確認している。

さて，FG は主としてホルマリンとグアヤコールから 成る製郕であるが，その急性毒性は上述のようにホルマ リンまたはグアヤコールを単独で投与した時よりもはる かに低かった・その一因として，FG にはグアャコール とホルマリンの他にこの両者よりも著しく毒性の低いエ チルアルコール24 が20\%の割合で配合されているとと が挙げられる.さらに，ホルマリンとクレゾールの配合 において，両者の相互作用による急性毒性の拮抗現象が 認められたように，クレゾールと同じくフェノール類に 属するグアャコールの場合にもホルマリンとの間に同様 の拮抗現象を生じ，そのためにホルマリンとグアヤコー ルの配合によって急性毒性が低下することも一因を成す と考えられる22'.

動物実験で得られる $\mathrm{LD}_{50}$ と人体における毒性との相 関関係を示す Deichman-Gerarde の表25) に彷えば，

FGはFC，グアャコール，クレゾールとともにその毒性 
は軽微である (slightly toxic) と判定され，また，通

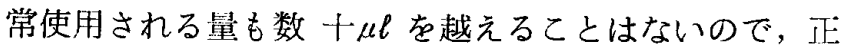
しい方法で使用される限り，FG の急性毒性はFC と同 様ほとんど心配する必要はないものと思われる。

結論

体重約 $20 \mathrm{~g}$ の dd Y系雄性マウスにFG，FC，グアヤコ ールおよびクレゾールを経口投与して急性毒性を比較検 討した結果，次の結論が得られた。

1. FGのLD ${ }_{5}$ は $1.81 \mathrm{~g} / \mathrm{kg}$ （95\%信頼限界1.56〜2.10 $\mathrm{g} / \mathrm{kg}$ ) であり，FC のそれは $1.72 \mathrm{~g} / \mathrm{kg} （ 95 \%$ 信頼限界 $1.51 \sim 1.96 \mathrm{~g} / \mathrm{kg}$ ）で両者の閒に有意差は認められなか つた(伦険率 $5 \%$ ).

2. FGを経口投与した場合の中毒症状は FCのそれと 類似し，マウスは一時興舊状態を呈した後，自発運動は
停止し，眼裂縮小および立毛が現われ，やがて病杽を起 こし，全身側位となり，あるいは伏臥位のまま麻猈状態 に移行し，呼吸停止により死亡した。

3. グアヤコールの $\mathrm{LD}_{50}$ は $0.89 \mathrm{~g} / \mathrm{kg} \quad(0.75 \sim 1.05$ $\mathrm{g} / \mathrm{kg}$ ) であり， クレゾールのそれは $0.76 \mathrm{~g} / \mathrm{kg}(0.66 〜$ $0.87 \mathrm{~g} / \mathrm{kg}$ ) で両者の間に有意差は譛められなかった（危 険率 $5 \%$ ) .

4.グアャコールを経口投与した場合の中毒症状はク レゾールのそれと類似し，FGよりも作用発現は迅速 で，投与後数分で立毛，振戦，眼裂縮小，および流涎が 見られ，やがて泣鳴を伴う激しい病杽を起しし，全身側 位となってしだいに麻瘦状態へ移行し，呼吸停止した。

5. FG の急性毒性は単味のグアャコールのそれより も明らかに低いが，FC との間にほとんよ゙毒性の差異は 想められなかった。

\section{引用 文 献}

1 ) Bartels, H.A. : A bacteriologic appraisal of some materials used in root canal therapy. J.A. D. A. $28: 1108-1112,1941$.

2 ) Pear, J.A. : Bactericidal effect of some drugs used in pulp canal therapy. J.A.D.A. 29: 244$248,1942$.

3 ) 真泉平治：菌科用消毒薬の研究, 第 1 報基礎的根管消毒薬の樑達性並びに消毒作用の比較研究. 歯科学杂倠誌 $9: 7-11,1949$.

4) 吉村泰治：歯科領域に繁用されている消毒剤の抗真菌作用について. 歯基礎誌 $19: 110-129 ， 1968$.

5) Treaner, H.F. and Goldman, M. : Bactericidal efficiency of intracanal medicaments. Oral Surg. $33: 791-796,1972$.

6) Cwikla, J.R. : The vaporization and capillarity effect of endodontic medicaments. Oral Surg. $34: 117-121,1972$.

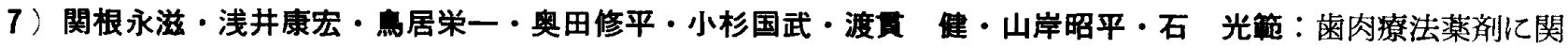
する臨床病理学的研究，特にフォルモクレゾールの露出損傷歯髄におよぼす影響について．蒾科学報 $71: 2063,1971$.

8 ) Loos, R.J., Straffon, L.H. and Han, S.S. : Biological effects of formocresol. J. Dent. Child. $40: 193-197,1973$.

9) 三条大助・米沢範子・山本蕗子・引地恵夫：FC の組織反応に関する実験的研究（II）病理組織変化につい て. 日歯保誌 $18: 264-267,1975$.

10）川口 充・井本邦应・松本仁人・堤 璋二：Formocresol の毒性および成分の経時変化について，橉基礎 誌 $20 ： 279-284,1978$.

11）黒木賀代子・竹中栄子・緒方智香子・小野弘子・村上雄次・吉村泰治：紫外部吸収スハクトル分析法とガス クロマトグラフ分析法の併用により観祭された FC 中の cresol の経日変化. 柬基礎誌 20:659$668,1978$.

12）黑木賀代子・竹中栄子・小野弘子・村上雄次・中島京子・吉岡伴子：Formocresol の経日変化に関する研 究 9. 成分変化の機構に関する考察ならびに成分変化に伴う消毒作用の変化. 日雨保誌 $21: 176-$ $185,1978$. 
13）踭田公二：2，3 殺菌性界面活性剤を配合した formalin 合剂の根管消毒剤としての基礎的研究. 歯科医学 $34: 467-493,1971$.

14）前田和男・柳川一征・熱田意也・渡贯 健・大塚弘介・山岸昭平・浅井康宏・石川達也・関根永滋：木ルマ リン・グアヤコールの䨑内療法領域における臨床応用成績（第 1 報） 歯科学報 67：878一884, 1967 .

15）坂本真吾・中岛俊明・内田武志 - 河内勝和 - 白川正治 - 東 富恵・二宮順二・安田博一・穴村紳一・吉岡道 治・小川哲次・白根 忠・平岛泰子・岡本 莫：根管治療剤ホルマリン・グアャコールの臨床成績につ いて. 日歯保誌 $21: 703-712,1978$.

16）前川成男：ホルムアルデヒド合剤に関する臨床病理学的研究（第 1 報） 露出損傷䨑骾に及に゙す影響につい て. 電科学報 $80: 1531-1574,1980$.

17）前川成男：ホルムアルデヒド合剤に関する臨床病理学的研究（第 2 報）麻酔拔瞇創に及ぼす影響について。 歯科学報 $80: 1577-1589,1980$.

18）西川殷維・安田博一・金城鼠次・平田博則・坂本真書・岡本 英・辻本 明：根管治療剂ホルマリン・グア ヤコールの慫性毒性について. 広大雬誌 $10: 213-217,1978$.

19）二木㫒瑞・堤 璋二・岛 秀一・前川成男・近藤祥弘・布施絵理子・小岛慎也・浅井康宏：各種根管治療消 毒剤の急性毒性実験成績について. 㭔科学報 $79: 569-574,1979$.

20）二木昇瑞・猪守忠久・堤 㻔二：Formalin-guaiacol の毒性および成分の経時変化について. 蒾基礎誌 $21: 348-353,1979$.

21）白須泰彦・吐山僼秋・編：毒性試験ハンドブック，フシテクノシステム，東京， $1980 ， 55-60$.

22）黑木賀代子・竹中栄子・吉岡伴子・村上雄次・吉村泰治：急性毒性における 药科用薬物の配合効果 1 . phenol と camphor の配合および formalin と cresol の配合について 粜基礎誌 22:144一155, 1980 .

23）秦 多恵子・尾陰多津子・三宅義雅・喜多富太郎：実験動物の急性毒性におよぼす薬物投与時刻の影響・日 薬理誌 $71: 29-37,1975$.

24）池田良雄：薬物致死量集. 南山堂, 東京, $1977,16-71$.

25) Deichman, W.B. and Gerarde H.W. : Toxicology of drugs and chemicals. (The reverse of the cover). Academic Press, Inc., New York, 1969 